УДК: 378.1

DOI $10.21661 / \mathrm{r}-555711$

\title{
С.Ю. Аверьянова
}

\section{ОРГАНИЗАЦИЯ УЧЕБНЫХ ЗАНЯТИЙ ПО МАТЕМАТИКЕ В ВУЗЕ С ИСПОЛЬЗОВАНИЕМ ДИСТАНЦИОННЫХ ТЕХНОЛОГИЙ}

Аннотация: в данной работе автором рассмотрены возможности использования дистанционных платформ для преподавания математики в вузе, позволяющих взаимодействовать со студентами в условиях реального времени. Исследователь отмечает положительные аспекты внедрения дистанционных технологий в учебные заведения и возникающие проблемь.

Ключевые слова: дистанционные технологии, преподавание математики, Microsoft Teams, перевернутьй класс, вуз.

Современное состояние нашего общество, перспективы его развития требуют от системы высшего образования подготовки кадров нового поколения специалистов, владеющих высокоэффективными технологиями, современными информационными инструментами. В 69 статье Ф3 «Об образовании в Российской федерации» определена основная цель профессионального образования обеспечение подготовки высококвалифицированных кадров по всем основным направлениям общественно полезной деятельности в соответствии с потребностями общества и государства, удовлетворение потребностей личности в интеллектуальном, культурном и нравственном развитии, углублении и расширении образования, научно-педагогической квалификации [1]. Математика является той дисциплиной, которая закладывает фундамент для достижения заявленной цели: играет особую роль в становлении и развитии научного мировоззрения студентов любых направлений подготовки, совершенствовании умственных способностей, базой для изучения общеинженерных дисциплин в техническом направлении, специальных дисциплин в экономическом.

Сегодня состояние окружающего нас мира вошло в стадию появления новых вызовов, не проявлявшихся ранее, или не распространяющихся столь 
обширно. Несомненно, что таким вызовом стала пандемия COVID-19. Распространение данной пандемии заставило проектировать новую «реальность», искать новые эффективные подходы и методики обучения математике в условиях ограничительных мер. В Южном федеральном университете для совместной работы и взаимодействия преподавателей и студентов выбраны возможности Microsoft Teams - cepвиса, который является частью облачной платформы Office365, позволяющий организовать онлайн обучение.

Данный сервис имеет широкий спектр для организации удаленного обучения и позволяет:

- создавать Команды для организации обучения в группах студентов;

- предоставлять студентам доступ к учебным материалам и файлам;

- назначать и проверять индивидуальные и групповые задания, выдавать их обучающимся, отслеживать своевременное выполнение и осуществлять проверку; а студентам - узнавать сроки, сдавать работы и получать оценку;

- создавать виртуальные классы, предоставляя студентам возможность делать презентации или совместно пользоваться цифровой доской;

- преподаватели и студенты могут взаимодействовать, используя не только доску, а также текст, аудио или видео;

- организовывать проведение вебинаров, видео-лекций или практических онлайн-семинаров, которые могут быть записаны для просмотра в офлайн режиме.

Таким образом, главным преимуществом данного инструментария является возможность проводить общение между студентом и преподавателем в реальном времени, сохраняя все формы проведения занятий и контроля, что является отличительной чертой очного обучения. Однако использования Microsoft Teams, как и других дистанционных платформ, требует огромных усилий от всех участников образовательного процесса.

Мы считаем, что прежде всего преподавателю надо произвести тщательный отбор важнейших математических понятий, необходимых для дальнейшего изучения студентами специальных дисциплин, найти «золотую середину» между 
фундаментальностью математического знания и доступностью его понимания, так как уровень как математической, так и общеучебной подготовки первокурсников неоднороден. Преподавание на дистанционной платформе требует визуализации теоретического материала, так как привычные атрибуты лекционного занятия - мел и доска становятся неактуальными. В связи с этим на преподавателя ложится дополнительная нагрузка по подготовке качественных учебных презентаций, которые могут служить обучающимся опорными конспектами. На данной платформе они могут размещаться как сразу на весь семестр обучения, так и последовательно после каждого проведенного занятия.

В данных условиях положительно зарекомендовала себя технология «перевернутого класса». Перевёрнутый класс (англ. flipped classroom) - принцип обучения, при котором основное усвоения нового материала студентами происходит дома, а время аудиторной работы выделяется на выполнение заданий, упражнений, проведение лабораторных и практических исследований, индивидуальные консультации преподавателя. Мы используем данную технологию, когда теоретический материал частично знаком студентам на основе школьного курса математики. Данная технология позволяет подавать теория с использованием дистанционных технологий в форме параграфов, статей, видеоматериалов, презентаций, ссылок на нужные учебники. Возможно записать собственные видеолекции и разместить в Команде в качестве теории. Второй вариант использования данной технологии направлен на развитие универсальных компетенций - студенты должны сами учиться искать информацию и обрабатывать её. При таком подходе мы не даем конкретных материалов для изучения, а только называем тему и круг рассматриваемых вопросов. Тогда задача студента - самостоятельно найти и проработать теоретический материал и прийти на занятие с конкретными вопросами, отрабатывать практические навыки. Второй вариант возможно применять только в случае неоднократного успешного применения первой формы организации «перевернутого класса».

Актуальным в данном ситуации, когда невозможен визуальный контакт, становится лекторское мастерство преподавателя: голос, ритм речи, 
эмоциональные «крючки», тайм менеджмент. Эмоциональная окраска лекции, сочетаясь с научным содержанием, создает гармонию мысли, слова и восприятия слушателями [2].

Курс вузовского математического образования всегда ориентирован на достаточное количество часов практических занятий, на которых происходит обобщение, систематизацию, углубление теоретических знаний, формирование умений применять полученные знания в практической деятельности. В формате обучения с помощью Microsoft Teams данная форма занятий может быть организована посредством встроенной интерактивной учебной доски, на которой, как в аудитории, проводится разбор решения типичных примеров. Плюсом данного инструментария является возможность распределения ролей: преподаватель выполняет решение, которое доступно всем присутствующим на занятии, или предоставляет возможность студентам, оформить решение предложенного задания.

Система Microsoft Teams позволяет создавать индивидуальные и групповые задания для самостоятельной работы и контроля знаний. Преимуществом данной функции является возможность настройки сроков выполнения заданий по дате и времени, а студент получает уведомление об опубликовании нового задания. Результаты выполненных студентами работ доступны преподавателю для оценивания, отправления на доработку, комментирования. Данная информация отражается и в личном кабинете студента.

Еще одним неоспоримым плюсом, который появился у студентов с использованием дистанционных технологий, является возможность многократного прослушивания учебных занятий, так как ведется потоковая запись и сохраняется в созданной Команде.

Выводы. Достижение освоения необходимого уровня математической подготовки в вузе в условиях ковидных ограничений возможно с помощью различных дистанционных платформ, на которых возможно взаимодействие в условиях реального времени. 
Однако, организация дистанционное обучение требует больших временных затрат преподавателя на подготовку к различным видам занятий. Отсутствие прямого контакта, визуального общения лишает возможности реализовывать воспитательную функцию предмета, так как только личный пример помогает передавать интерес к знанию, жизненный и культурный опыт, традиционные российские ценности.

Таким образом, дистанционное обучение в настоящее время должно восприниматься как одна из современных форм обучения, которую можно использовать только в совокупности с известными классическими.

\section{Сиисок литературы}

1. Федеральный закон от 29.12.2012 N 273-Ф3 «Об образовании в Российской Федерации (ред. от 02.07.2021; с изм. и доп., вступ. в силу с 01.09.2021)// Доступ из справочной правовой системы «КонсультантПлюс» [Электронный ресурс]. - Режим доступа: http://www.consultant.ru/

2. Куприянова Л.М. Педагогическое мастерство: принципы оценки // Высшее образование в России. - 2003. - №1. - С. 78-80.

Аверьянова Светлана Юрьевна - канд. пед. наук, доцент кафедры информатики и математики, ФГАОУ ВО «Южный федеральный университет», Новошахтинск, Россия. 